\title{
The Effect of Social Media Following on Recruitment in Service Industries of Pakistan
}

\author{
Samawiya Aqeel (Corresponding author) \\ Karachi University Business School, University of Karachi, Karachi, Pakistan
}

Tel: 92-331-307-4112Ｅ-mail: samawiyaaqeel6@gmail.com

\begin{abstract}
Danish Ahmed Siddiqui
Associate Professor, Karachi University Business School, Karachi University Business School, University of Karachi, Karachi, Pakistan

Tel: 92-333-348-5884Ｅ-mail: daanish79@hotmail.com
\end{abstract}

Received: March 19, 2019 Accepted: April 14, 2019 Published: April 19, 2019

doi:10.5296/bms.v10i1.14633～URL: https://doi.org/10.5296/bms.v10i1.14633

\begin{abstract}
Social technologies are progressively utilized in a few hierarchical capacities, as well as human resource management. The focal point of this research is by social media based reception in recruitment of employees in service industries in Pakistan. More specifically, the focal point of this study is the Use and Acceptance of Technology which is through social media by HR experts in the recruitment procedure and selecting representatives. Results acquired utilizing cross-sectional information gathered from 80 enrollment specialists through close ended Likert scale questionnaire. It was later analyzed using Descriptive analysis, CFA and Structured Equation Modeling. The results demonstrated that the center theories of the Acceptance and Use of Technology in recruitment through social media by HR experts were upheld. There was a positive effect of performance expectancy, effort expectancy and social impact on recruiter's intention to use these technologies recruitment. Moreover, facilitating or encouraging conditions and social goal impactful affect the enrollment (Recruitment) specialist's usage behavior or conduct. There is an impulse effect of different moderators like gender, age, education, and managerial position such as the effect is robust for male, younger and high positioned recruiters while most of the experienced
\end{abstract}


recruiters still emphasize on traditional approaches but beside all these social media seem to have an important impact in the process of recruitment.

Keywords: Technology adoption, Social media, Recruitment, Service Industries, Pakistan, CFA, SEM 


\section{Introduction}

Social advancements are utilized in numerous hierarchical capacities and for a few purposes. Literature reviews of social media exploration deliver indication on their use in safety and crisis communication (Veil, Buehner, Palenchar, \& management, 2011), marketing and sales (Andzulis, Panagopoulos, Rapp, \& Management, 2012), public relations (Khang, Ki, Ye, \& Quarterly, 2012), sharing of knowledge and knowledge management (El Ouirdi, El Ouirdi, Segers, Henderickx, \& Technology, 2015), and managerial and organizational communication (Ngai, Tao, \& Moon, 2015). Social media can also be a helpful and provide support in human resource management which includes hiring and enrollment process (Wolf, Sims, \& Yang, 2014). The utilization of social media in the process of recruitment of employees, often denoted as 'social recruiting', which includes different procedures and offers numerous benefits. Recruitment specialists utilize different platforms such as LinkedIn, Facebook and Twitter for the job post ads, employee job applicants, and pre \& post screening of applicants (Caers \& Castelyns, 2011; Cain, Scott, \& Smith, 2010; Melanthiou, Pavlou, \& Constantinou, 2015; Ollington, Gibb, \& Harcourt, 2013; Pike, Bateman, \& Butler, 2013; Zide, Elman, \& Shahani-Denning, 2014). Because of this usage of Social media, the enlistment procedure turns out to be progressively unique, social, and genuine, and the business brand and engaging quality are upgraded (A. Carrillat, d'Astous, \& Morissette Grégoire, 2014; Girard \& Fallery, 2011; Henderson \& Bowley, 2010).

The significance of considering use of social media in enrollment or hiring and determination originates from the basic job of staffing rehearses in the present progressively focused and worldwide talent showcase. (Ployhart, 2006). The participation of innovation in hiring is turning into a need for managers wishing to have an upper hand in the work advertise, and pull in rare basic ability or talent (Deloitte Consulting \& by Deloitte, 2014). The investigation of subject will thus provide abundant applied implications for employers and fill some interesting and organizational gaps in research.

\subsection{Background of Study}

Current difficulties and changes in innovation and the job of the Internet open up new open doors for organizations to communicate and work. The way that Social Media Networking Sites entered in the business scene, and specifically the hiring and enrollment programs prompts an interest for learning about recruitment patterns with respect to Social Media Networking Sites. With this investigation the marvels of Social Media Networking Sites in enlistment was investigated. Learning was gained by utilizing a review, directed in Pakistan's organizations. The accompanying exploration question is replied inside this theory: To what degree does the utilization of Social Networking Sites lead to viable enrollment?

To address the examination question and to recognize the degree to which the utilization of Social Media Networking Sites prompts viable hiring, an exploratory research demonstrate was built up so as to discover connections between the characteristics of Social Media Networking Sites and compelling enlistment. The picked characteristics of destinations were 
data quality, prominence, organizing extension, simplicity of route and security/protection. Powerful enrollment is described by the decent variety of candidates, the nature of candidates/applications, the costs, the time and the objective gathering introduction. Additionally, the sort of the site (business or corporate sites versus social-media oriented sites) assumed an essential job in this exploration.

\subsection{Problem Statement}

In spite of the fiscal and monetary emergency, the talent war still n real topic, and companies are challenged with the problematic discovery for the right employees, still there are unfilled vacant position and companies have staffing problems (Garcia-Retamero, Galesic, \& medicine, 2010). Michaels, Handfield-Jones, and Axelrod (2001) claimed that there is a new business reality regarding staffing and other HR strategies which not only facilitates recruiters but also for the candidates. Organizations need individuals to endure, talented individuals are a prime hot spot for an organization's upper hand, and skilled individuals are rare. The look generally advantageous and the most brilliant individuals is a steady fight among organizations, and they need to create procedures so as to locate the best representatives of the company. Therefore, the key inquiry of finding, drawing in and selecting the best individuals has turned into an applicable issue for organizations. Besides, the Internet has changed the manner in which individuals impart and work (Giles, 2010). Through the entering of Social Media Sites into business scenario and the quickly developing measure of these sites, a need of procedure for finding a path through this wilderness of destinations is required. Organizations will in general be not clear about which applications are the best for their hiring and enrollment procedure. Social communication or social media sites and its effect on hiring is an exceptionally ongoing field which is quick moving and along these lines hard to screen state-of-the-art.

Recruitment or hiring through Social Networking Sites is another theme and there is an absence of learning about it. Hence, the recruitment specialist (researcher) chose to direct an examination in Pakistan so as to discover how Pakistan's organizations manage this new and real subject.

The primary target of this investigation is to distinguish to what degree the utilization of Social Media Sites prompts powerful hiring. An additional objective is to discover how much these Social Media Sites significant to any organization.

\subsection{Gap Analysis}

The present investigation motivated by four essential loops in the current literature via web-based networking or social media usage in individual's selection process. Initially, while social media appear to pick up prominence in worker hiring procedure and practices, numerous researchers noticed a noteworthy loop among research and practice, with early scholastic research being fundamentally non-experimental and lacking sound hypothetical establishments of assumptions (El Ouirdi et al., 2015; Gibbs, MacDonald, \& MacKay, 2015; Roth, Bobko, Van Iddekinge, \& Thatcher, 2016; Van Osch \& Coursaris, 2015). Furthermore, 
the research is particularly needed on social media usage in organizations to address questions concerning the factors that enable their adoption to use social media sites in recruitment process (Ngai et al., 2015).

Secondly, regardless of the recognition of the "Theory of Acceptance and Use of Technology” as a model of innovation appropriation in the administrative setting, just few examinations connected it exactly (Taiwo, Downe, \& Technology, 2013; Williams, Rana, Dwivedi, \& Lal, 2011), hence the need for additional repetition. Third, research on technology implementation in hiring tends to emphasis on the U.S. context and on the applicants' viewpoint (Crisp, Anderson, Orme, \& Lister, 2003). This breach prompts the requirement for more research from the hiring managers. Fourth, given the significance of employer's qualities, for example, skill with new advancement in abilities, identity, and instructive dimension, and their effect on development reception in determination (Crisp et al., 2003), there is necessity to inspect more employer's characteristics such as education and managerial position.

In this way, this examination adds to the literature in three primary ways: we add to the rising however developing group of observational proof via social media networking appropriation in hiring; we center around the selection representatives' viewpoint, and explore online networking use in the under-investigated in Pakistan; and we recreate the UTAUT model which display and expand it by joining the employers' administrative position and instructive dimension as potential moderators.

\subsection{Research Question}

The overall implications of research of the use of social media in recruitment process and its impact in service industries in Pakistan aimed to answer the following research questions:

1. Why and how HR departments use social media tools for the recruitment process?

2. What do HR Departments observe as the costs and benefits of using social media in the process of recruitment?

3. What risks involve in using social media by HR Department in the process of recruitment?

4. Does recruitment through social media has any impact on performance in the workplace in service industries?

5. What are the effects of this research for delivery of assistance HR managers and HR departments on using social media tools for the purpose of recruitment?

6. Do the services industries use social media to attract suitable applicants for jobs in their organizations?

This research has aimed to response these questions by means of a literature review and questionnaire tool that have used social media for the recruitment purposes. 


\subsection{Significance of Study}

The Higher management and managers of any company motivate supporters and staff to work by sharing and imparting the vision of the organization so the recruitment of top managers should be done in a way that they contribute towards organization in positive way. Globally, HR Departments uses Social Media tools to search for the best candidate who fits best in their organization.

Social media seems to advance attractiveness in recruitment process but it is observed that there is a significant gap between research and practice in the area of recruitment. This study is conducted to by the viable characteristics of recruitment through social media which fundamentally effect on the workplace by sharing their part in organizations functions.

This research gives the importance of recruitment through social media by characterizing different attributes in details, such as competence with new technologies, personality, and educational level, and their impact on performance. This research study also contributes to the literature in a dynamic means, this study contributes to empirical evidence on social media adoption in recruitment process in services industry in Pakistan. This study focuses on the recruiters' perspective, and investigate social media usage in the under-researched region of urban areas of Pakistan.

1. It will be easy to get secondary data for future researcher.

2. It will help HR practitioners to identify either what benefits and opportunities we can facilitate by hiring through social media.

\subsection{Limitations of Study}

Limitations of the research study can be drawn as following.

1. The research sample is limited to Service industries with the geographic division of urban areas of Pakistan.

2. Selection of sample as responses may vary as per size, location and scopes of organization.

3. Due to lack of time and resources sample was collected from few random services industries in Pakistan.

4. The study is only a portrait in time and the usage of Social Media Networking Sites is a fast moving subject which has to be monitored for a longer period of time.

\subsection{Outline of Study}

Pursued by the information investigation and discoveries. At last, the outcomes are talked about and inquire about confinements featured. Future research recommendations and administrative ramifications are additionally exhibited. 


\section{Literature Review}

As a developing field, there is minimal past scholarly research or observational examination concentrating on SM in a HR setting, and even less in the administration enterprises. Therefore, the writing survey concentrates more on SM in a HR setting than taking a view at it from an administrations or representative's setting of the few examinations got to, one had a more extensive degree tending to wonders from the activity competitor's viewpoint, versus a business point of view (Madera, 2012). Flow inquire about for the most part shows the commonness, advantages, and weaknesses of SM and HR as a pattern identified with the hiring and screening procedure of potential representatives. As per the (Crisp et al., 2003), reacting HR experts demonstrated utilization of LinkedIn (95\%), Facebook (58\%) and Twitter (42\%) for recruitment purposes, predominantly focusing on non-executives salaried workers (82\%) and other administration positions, exclusive of upper administration (77\%). Besides, of the 18 percent of HR experts utilizing SM to screen applicants, 30 percent stated utilizing data from SM to exclude an applicant. These HR experts likewise revealed utilizing LinkedIn (85\%), Facebook (78\%), and Twitter (11\%) to screen contender for upper administration (41\%) and non-executives salaried positions (26\%)

While incredulity of SM's place in the business world exists, benefits relevant with recruitment, marking, and expenses are getting to be solid countervailing factors. SM can be a useful technique for producing referrals regarding hiring the applicants (Smith \& Kidder, 2010) and has outperformed online occupation sheets as the favored method to obtain ability (Brotherton, 2012). HR chiefs are amplifying the capacity of SM through utilization of their representatives' informal communities as a cost-cognizant methodology known as 'social enlistment' (Doherty, 2010). This inclination is to some extent because of the development of the ability pool through online systems, for example, LinkedIn, Facebook and Twitter, which encourage worldwide versus local enlistment (Brotherton, 2012).

The help of e-enlistment accommodation decreases the time to recruit by giving enrollment specialists the opportunity to post occupations online with a tick and by empowering candidates to answer speedily by finishing on the web frames and by basically appending CVs to emails. Time-to-contract is the ideal opportunity for the entire enlistment process from the recognized opening to the fruitful filling of these opportunities. By utilizing the Internet, the ideal opportunity for these procedures is diminished and can influence the association's returns. Silverman (2016) demonstrates that organizations anticipate that online exercises should accelerate the enlistment procedure. (Festing, Schäfer, \& Scullion, 2013) reasons that $67 \%$ of the greatest Pakistan organizations see potential to improve their enlistment procedure with e-enrollment. They accept a substantial relationship between the cost decrease and the usage of e-enlistment related time-saving throughout the hiring and management procedures. This can positively affect business income. Pin, Laorden, and Saenz-Diez (2001) indicate in their paper that, rendering to study brought out among 500 American organizations, the primary preferred standpoint of e-enrollment is time saving. $86 \%$ of the asked organizations concurred on this. Through e-enlistment, associations have 
the upsides of a quicker posting of occupations, quicker candidate reaction and a quicker handling of list of qualifications. Along these lines, it accelerates the enlistment procedure and abbreviates an opportunity to-procure. A period of recruitment is normally estimated in days and emulates the complete time required to staff an open vacant position (Abel, Gao, Houben, \& Tao, 2011). Person to person communication Sites as an issue in e-enlistment can henceforth prompt efficient between enrollment forms. Upheld by these destinations, enrollment specialists can post employments and screen candidates in a brief time period.

worth of candidates/applications Looking at Festing et al. (2013), the extent of enrollment advertising by means of social sites getting broader and thus the recruiters brand builds up itself and prompts a superior value of the applications. Festing et al. (2013) gives no sign with regards to the level of organizations which expect an improvement of the nature of candidates through e-enrollment. Pin et al. (2001) refer to an examination, among 500 organizations in USA, in which $20 \%$ of the taking an interest HR administrators state that the screening out of under-qualified applicants is a major benefit of e-enlistment and makes it conceivable to improve the quality of the candidates/applications. As per the two writers, e-enlistment prompts a higher quality of candidates/applications and in this way it tends to be expected that the utilization of Social Networking Sites positively affects the quantity of qualified candidates/applications too.

A few investigations propose that SM ought to be coordinated and supplement existing enlistment techniques as opposed to supplanting them (Hunt, 2010) and that SM is never again separate from any business work, and considerably can possibly be incorporated into every day exercises, add to progress over an assortment of business targets, and effect the main concern (Berkowitz, 1987). Discoveries from Pelit, Öztürk, and Arslantürk (2011) propose that relations with associates, correspondences, and the board input are drivers of representative fulfillment, which could all be bolstered by SM. The utilization of SM, nonetheless, requires system for the varying stages (e.g., Facebook, LinkedIn) (Hunt, 2010) and contrasting gatherings of people (e.g., current workers versus potential representatives) to receive its rewards. Gibbs et al. (2015) depicts one such inward advantage as 'social HR,' whereby SM upgrades associations as a result of cooperation and network, just as the oft referred to outside advantage to discuss extensively with potential ability. SM has capacities past the ID of potential applicants, as a driver to draw in, brand, and hold workers while utilizing every representative system for further development (Berkowitz, 1987).

Use of Social Media in a Human Resource framework isn't without its disadvantages. Damages of Social Media are apparently magnified in Human Resource context, such as statutory and moral concerns. shortage of proper policies for the usage of Social Media, and concerns of trustworthiness and dependability of data obtained from Social Media (Edition, 2010; Slovensky \& Ross, 2012; Smith \& Kidder, 2010). candidate's Social Media profiles are ordinarily made for social reasons and in this way data revealed about an applicant could be random to work execution and seen contrarily by the hopeful as an attack of protection (Slovensky \& Ross, 2012). The level of lawful hazard is to some degree obscure yet can 
emerge from introduction to ensured hopeful qualities, for example, age, incapacity, or sexual introduction. Moreover, on the grounds that Social Media stages don't mirror the socioeconomic of the overall public, associations depending vigorously on these stages may have a dissimilar effect and hazard for not guaranteeing all gatherings have an equivalent employment chances or opportunity. (Edition, 2010). Also, because of the straightforwardness at which forged profiles and incorrect labels and posts can be made, organizations will most likely be unable to depend certainly on Social Media profiles and exercises as a reason for screening candidate.

In the earlier stated Society for Human Resource Management study, 56\% of organizations specified that they don't have a strategy concerning for the usage of Social Media Networking sites. Also, 29\% testified that their business strategies are to devise a strategy within a year which demonstrate an increased development in adoption of use of social media (Gibbs et al., 2015). Associations that are not utilizing Social Media for screening of applicants express worries about lawful dangers including finding data about secured qualities (66\%), the failure to confirm data from a candidate's Social Media profile (48\%) and data on employment applicants from SM profiles may not be pertinent to business related prospective (45\%) (Gibbs et al., 2015). The touchy development of Social Media utilization and instruments has made it troublesome for some HR supervisors (and employment applicants) to keep speed (Brotherton, 2012). The rapidity of progressions has made an extra worry for Human Resource administrators to comprehend which SM applications will meet their particular Human Resource needs.

\section{Theoretical and Conceptual Framework}

In the accompanying segments, the investigation's hypothetical foundation is exhibited alongside a concise audit of past research by Venkatesh, Morris, Davis, and Davis (2003) on the bound together hypothesis of unified theory of acceptance and use of technology (UTAUT) application to internet based (Social Media) selection/ hiring. Next, the examination speculations are given a proposed expansion of the model with the employers representatives' managerial position and instructive dimension (Hanson et al.) as moderators.it is clear to characterize UTAUT before going to additionally ponder The brought together hypothesis of acknowledgment and utilization of innovation is an innovation acknowledgment demonstrate figured by Venkatesh et al. (2003) in "User acceptance of information technology Toward a unified view". The Unified Theory of Acceptance and Use of Technology" aims to enlighten user intents for the usage managing information system and following usage behavior. The theory holds the four key constituents: i.) performance expectancy, ii.) effort expectancy, iii.) social influence, and iv.) facilitating conditions.

The models consolidated in the UTAUT are the hypothesis of contemplated activity, the innovation acknowledgment show, the inspirational model, the hypothesis of arranged conduct, a model joining the innovation acceptance model and the hypothesis of arranged conduct, the model of Computer System usage, the development dissemination hypothesis, and the social subjective hypothesis. The utility of the observationally tried and 
cross-approved UTAUT lies in its capacity to enable directors to evaluate the probability of progress for new innovation presentations, and comprehend the drivers of their acknowledgment or acceptance so as to proactively structure intercessions focused at clients that might be less disposed to receive and utilize new frameworks during the time spent enlistment (Venkatesh et al., 2003).

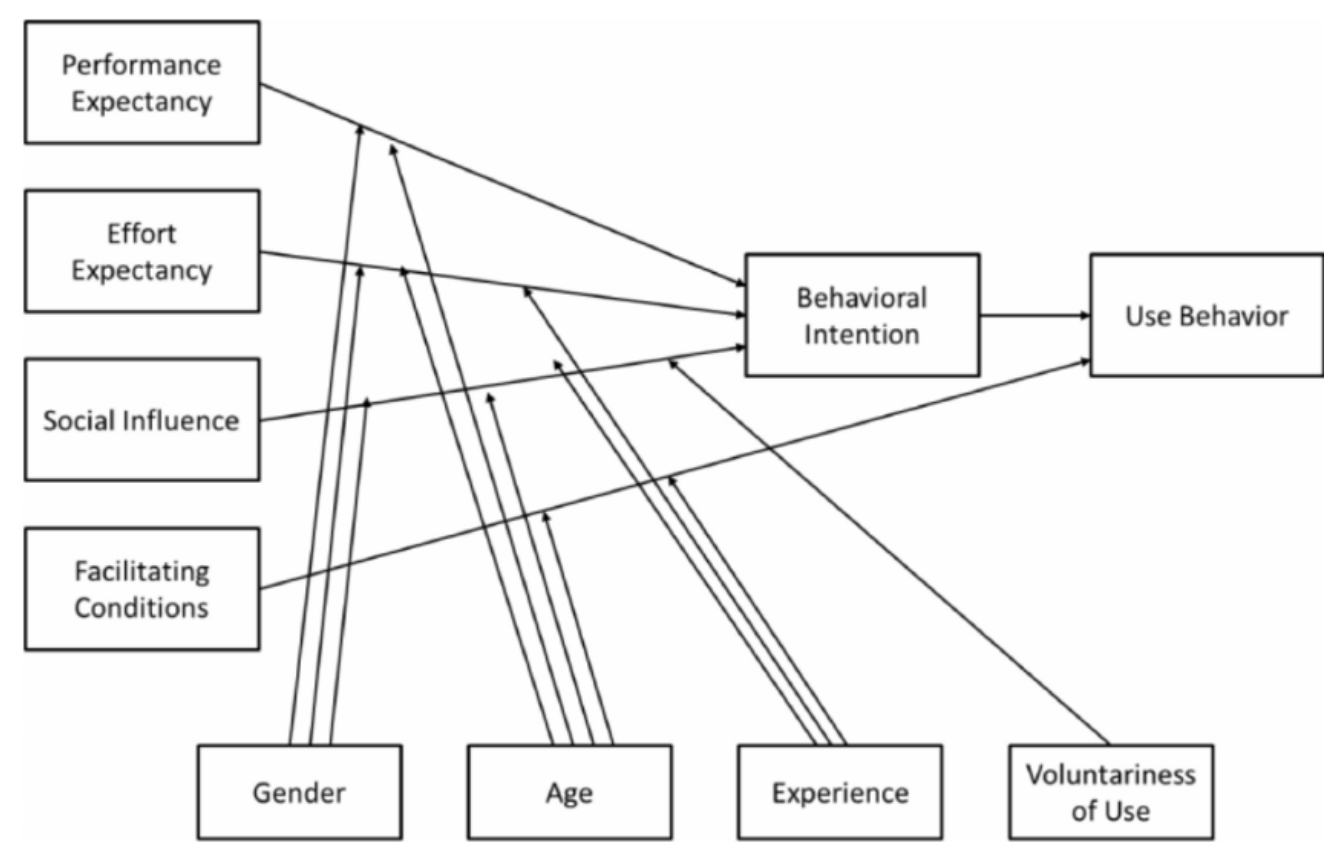

Figure 1. The Unified Theory of Acceptance and Use of Technology

The fundamental component in all the models is the behavior of use of social media, such that, use of new technology in any processing related to business operations. In an authentication of the recognition and usage of computer software by Human Resources in process of recruitment and selection. The model assumes two direct causes of use: 'intention to use of SM' and "facilitating conditions". "Intention to use" is in turn subjective by "performance expectancy"; "effort expectancy" and "social influence”. Age, Gender, experience and voluntariness of use act as moderators in the research.

This investigation numerous communication impacts are relied upon to be activated by gender, age, involvement with the innovation under this study and willingness of utilization of social media. Also as indicated by the UTAUT demonstrate, the impact of execution hope on conduct goal is more grounded for youthful laborers; the impact of exertion anticipation on conduct expectation is more grounded for more established specialists, and those with restricted involvement with the innovation; the impact of social impact on conduct aim is more grounded for those with constrained understanding, in obligatory settings; and the impact of encouraging conditions on utilization conduct is more grounded for more established laborers with more involvement with the innovation (Venkatesh et al., 2003). Hanson et al. (2011) researched on social media usage by health educators, the 
communication effects activated by age or time for the relationships between performance and effort expectancies on the other hand, behavioral intention were in line with Venkatesh et al. (2003) original model.

\subsection{Research Hypotheses}

H1: Social media-related a) performance expectancy, b) effort expectancy, and c) social influence have positive impacts on the recruiter's intention to use these technologies in employee recruitment.

H2: Social media-related a) facilitating conditions and b) behavioral intention have positive impacts on the recruiter's usage behavior.

H3: The influence of performance expectancy on the behavioral intention to use social media in recruitment is moderated by a) gender, b) age, c) education, and d) managerial position such that the effect is stronger for male, younger, more educated, and high positioned recruiters.

H4: The influence of effort expectancy on behavioral intention is moderated by a) gender, b) age, c) experience, d) education, and e) managerial position such that the effect is stronger for female, older, less experienced, less educated, and low positioned recruiters.

H5: The influence of social influence on behavioral intention is moderated by a) gender, b) age, c) experience, d) education, e) managerial position, and f) voluntariness of use such that the effect is stronger for female, older, less experienced, less educated, and low positioned recruiters, in mandatory settings.

H6: The influence of facilitating conditions on usage behavior is moderated by a) age, b) experience, c) education, and d) managerial position such that the effect is stronger for older, more experienced, less educated and low positioned recruiters.

\section{Research Methodology}

\subsection{Method and sample}

The objective populace for this examination comprised of human asset experts associated with hiring. Information were gathered among January and February 2019, an email welcome to take an interest in the examination was sent to the respondents. This method guaranteed consistency crosswise over Pakistan as far as instrument position, information gathering, and overview timing. Moreover, a connection to the online overview was spread on the company's internet based accounts.

\subsection{Measures}

The online assessment was composed of close ended questions. Respondents of the survey were questioned to rate all social-media tools in bits and pieces on a five point likert scale extending from Strongly Disagree to Strongly Agree. Whereas, Strongly Disagree is denoted by 1 while the Strongly Agree is denoted by 5, It means the scale measures from least to 
maximum.

\subsection{Data Collection}

The information gathered for the examination is quantitative while attitudinal ability "Likert aptitude" is likewise use to remove data about the exploration issue from the chosen test. The example was chosen based on reasonableness for this investigation or research. Because of time and limited resources, the vast majority of the surveys were conveyed through google shapes (forms) and by circulation polls in various organizations inside Karachi.

\subsection{Demographic Analysis}

The demographic data's frequencies obtained from the investigation is given below:

Table 1. Gender Distribution

\begin{tabular}{|c|c|c|c|c|c|}
\hline \multicolumn{6}{|c|}{ Gender } \\
\hline & & Frequency & Percent & Valid Percent & $\begin{array}{c}\text { Cumulative } \\
\text { Percent }\end{array}$ \\
\hline \multirow[t]{3}{*}{ Valid } & Male & 44 & 55.0 & 55.0 & 55.0 \\
\hline & Female & 36 & 45.0 & 45.0 & 100.0 \\
\hline & Total & 80 & 100.0 & 100.0 & \\
\hline
\end{tabular}

Most of the respondents are males. almost 55\% respondents are males while rest $45 \%$ are females.

Table 2. Educational Level of Respondents

\begin{tabular}{|c|c|c|c|c|c|}
\hline \multicolumn{6}{|c|}{ Education } \\
\hline & & Frequency & Percent & Valid Percent & Cumulative Percent \\
\hline \multirow[t]{4}{*}{ Valid } & Undergraduate & 1 & 1.3 & 1.3 & 1.3 \\
\hline & Graduate & 32 & 40.0 & 40.0 & 41.3 \\
\hline & Post Graduate & 47 & 58.8 & 58.8 & 100.0 \\
\hline & Total & 80 & 100.0 & 100.0 & \\
\hline
\end{tabular}




\section{Macrothink}

Business Management and Strategy

ISSN 2157-6068

2019, Vol. 10, No. 1

The educational level of respondents is mainly Post Graduate, which is almost 58.8 percent of total population.

Table 3. Respondents Professional Experience

\begin{tabular}{|c|c|c|c|c|c|}
\hline \multicolumn{6}{|c|}{ Experience } \\
\hline & & Frequency & Percent & Valid Percent & $\begin{array}{c}\text { Cumulative } \\
\text { Percent }\end{array}$ \\
\hline \multirow[t]{5}{*}{ Valid } & 1-3 year & 33 & 41.3 & 41.3 & 41.3 \\
\hline & 4-6 year & 24 & 30.0 & 30.0 & 71.3 \\
\hline & 7-10 year & 15 & 18.8 & 18.8 & 90.0 \\
\hline & Above 10 years & 8 & 10.0 & 10.0 & 100.0 \\
\hline & Total & 80 & 100.0 & 100.0 & \\
\hline
\end{tabular}

Majority of the contributors of responses are having 1-3 years of experience which is almost 41.3 percent of the population.

Table 4. Respondents Age Group

\begin{tabular}{|c|c|c|c|c|c|}
\hline \multicolumn{6}{|c|}{ Age } \\
\hline & & Frequency & Percent & Valid Percent & $\begin{array}{c}\text { Cumulative } \\
\text { Percent }\end{array}$ \\
\hline \multirow[t]{5}{*}{ Valid } & $18-25$ & 18 & 22.5 & 22.5 & 22.5 \\
\hline & 26-30 & 45 & 56.3 & 56.3 & 78.8 \\
\hline & $31-40$ & 13 & 16.3 & 16.3 & 95.0 \\
\hline & $41-50$ & 4 & 5.0 & 5.0 & 100.0 \\
\hline & Total & 80 & 100.0 & 100.0 & \\
\hline
\end{tabular}

The respondents in this survey fit in to several age groups. But the major population lie in the age group of 26 to 30 years. 
Table 5. Respondents Managerial Position

\begin{tabular}{|c|c|c|c|c|c|}
\hline \multicolumn{6}{|c|}{ Managerial Position } \\
\hline & & Frequency & Percent & Valid Percent & $\begin{array}{c}\text { Cumulative } \\
\text { Percent }\end{array}$ \\
\hline \multirow[t]{5}{*}{ Valid } & Non Manager & 19 & 23.8 & 23.8 & 23.8 \\
\hline & Under Manager & 31 & 38.8 & 38.8 & 62.5 \\
\hline & Manager & 25 & 31.3 & 31.3 & 93.8 \\
\hline & Senior Manager and above & 5 & 6.3 & 6.3 & 100.0 \\
\hline & Total & 80 & 100.0 & 100.0 & \\
\hline
\end{tabular}

Most of the participant in this survey are working Under Managers that is 38.8 percent of the total population.

Table 6. Respondents Social Media Training

\begin{tabular}{|c|c|c|c|c|c|}
\hline \multicolumn{6}{|c|}{ Social Media Training } \\
\hline & & Frequency & Percent & Valid Percent & $\begin{array}{c}\text { Cumulative } \\
\text { Percent }\end{array}$ \\
\hline \multirow[t]{5}{*}{ Valid } & No & 51 & 63.7 & 63.7 & 63.7 \\
\hline & Yes & 29 & 36.3 & 36.3 & 100.0 \\
\hline & Total & 80 & 100.0 & 100.0 & \\
\hline & & & & & \\
\hline & & & & & \\
\hline
\end{tabular}

The majority of the respondents have not formal social media training in their organization, consisting 63.7 percent. 
Table 7. Respondents Voluntariness of Social Media Usage

\begin{tabular}{|l|l|r|r|r|r|}
\hline \multicolumn{7}{|c|}{ Voluntariness of social media use } \\
\hline \multirow{2}{|c|}{} & Frequency & Percent & Valid Percent & $\begin{array}{c}\text { Cumulative } \\
\text { Percent }\end{array}$ \\
\hline \multirow{2}{*}{ Valid } & Voluntary & 26 & 32.5 & 32.5 & 32.5 \\
\cline { 2 - 7 } & Highly Recommended & 38 & 47.5 & 47.5 & 80.0 \\
\cline { 2 - 7 } & Mandatory & 16 & 20.0 & 20.0 & 100.0 \\
\cline { 2 - 7 } & Total & 80 & 100.0 & 100.0 & \\
\hline
\end{tabular}

47.5 percent of participants highly recommend use of social media in recruitment process.

\subsection{Attitudinal Analysis}

Table 8. Attitudinal Analysis

\begin{tabular}{|c|c|c|}
\hline Questions & Mean & Std.Dev. \\
\hline \multicolumn{3}{|l|}{ Usage behavior in Stages of Hiring } \\
\hline $\begin{array}{l}\text { The determinations for which SM was used by Human Resource } \\
\text { managers were almost solely for raising awareness of their } \\
\text { Organization. }\end{array}$ & 4.18 & .808 \\
\hline $\begin{array}{l}\text { The purposes for which SM was used by Human Resource managers } \\
\text { were almost solely for attracting people to apply in their Organization. }\end{array}$ & 4.04 & .878 \\
\hline $\begin{array}{l}\text { The purposes for which SM was used by Human Resource managers } \\
\text { were almost exclusively for the hiring decision. }\end{array}$ & 3.61 & .961 \\
\hline $\begin{array}{l}\text { The purposes for which SM was used by Human Resource managers } \\
\text { were almost exclusively for interview. }\end{array}$ & 3.48 & 1.125 \\
\hline $\begin{array}{l}\text { The purposes for which SM was used by Human Resource managers } \\
\text { were almost exclusively for reference checking. }\end{array}$ & 3.65 & .982 \\
\hline
\end{tabular}


The purposes for which SM was used by Human Resource managers were almost exclusively for preliminary screening.

Usage behavior in Recruitment

Social Media was most useful for communicating directly with potential candidates.

Social Media was most useful for sourcing and identifying potential candidates.

Social Media was most useful for screening candidates.

Usage behavior across job types

\begin{tabular}{|l|l|l|}
\hline Social Media is useful for recruiting full time front line employees. & 3.89 & .779 \\
\hline Social Media is useful for recruiting part time front line employees. & 3.66 & .762 \\
\hline Social Media is useful for recruiting employees at management level. & 3.76 & 1.046 \\
\hline Social Media is useful for recruiting employees at supervisory levels. & 3.49 & 1.067 \\
\hline Social Media is useful for recruiting seasonal workers/ employees. & 3.46 & .913 \\
\hline
\end{tabular}

Behavioral intention

\begin{tabular}{l|l|l|}
$\begin{array}{l}\text { Keeping up with the growing use of social media is difficult for human } \\
\text { resource managers. }\end{array}$ & 3.49 & 1.201 \\
\hline $\begin{array}{l}\text { Social media is a cost effective tool for human resource purposes. } \\
\text { Social media is more effective for recruiting employees than more } \\
\text { traditional methods such as newspaper advertisements and job websites. }\end{array}$ & 4.34 & .655 \\
$\begin{array}{l}\text { Use of social media by human resource purposes has too many ethical } \\
\text { and privacy issues related to it. }\end{array}$ & 3.91 & 1.009 \\
\hline
\end{tabular}




\begin{tabular}{|c|c|c|}
\hline Social media should have a central role in the hiring process. & 3.88 & .973 \\
\hline Use of social media in human resources is a fad. & 3.17 & 1.220 \\
\hline I intend to use social media in the next 12 months & 3.91 & 1.058 \\
\hline \multicolumn{3}{|l|}{ Performance expectancy } \\
\hline I find social media valuable in my job & 3.91 & .917 \\
\hline Using social media increase my output & 4.09 & .845 \\
\hline \multicolumn{3}{|l|}{ Social influence } \\
\hline People who are significant to me consider I should use social media & 4.06 & .817 \\
\hline In general, my company supports the use of social media & 3.93 & .708 \\
\hline \multicolumn{3}{|l|}{ Facilitating condition } \\
\hline I have the resource necessary to use social media & 4.06 & .752 \\
\hline I have the familiarity essential to use social media & 3.74 & .938 \\
\hline A precise individual (or group) is obtainable for assistance & 4.15 & .677 \\
\hline \multicolumn{3}{|l|}{ Effort Expectancy } \\
\hline It is easy for me to dominant social media. & 4.09 & .750 \\
\hline
\end{tabular}

4.6 Descriptive Statistics of Responses

Table 9. Descriptive Statistics of Responses from Respondents

\begin{tabular}{|l|c|c|c|c|c|c|}
\hline Questions & Cons. & $\mathrm{N}$ & Min & Max & Mean & St.Dev \\
\hline
\end{tabular}




\section{Usage behavior in Stages of Hiring}

\begin{tabular}{|l|l|l|l|l|l|l|}
\hline $\begin{array}{l}\text { The purposes for which Social Media was } \\
\text { used by Human Resource managers were } \\
\text { almost exclusively for rising awareness of } \\
\text { their Organization. }\end{array}$ & UBH1 & 2 & 5 & 4.18 & .808 \\
\hline $\begin{array}{l}\text { The purposes for which Social Media was } \\
\text { used by Human Resource managers were } \\
\text { almost exclusively for attracting people to } \\
\text { apply in their Organization. }\end{array}$ & UBH2 & 80 & 1 & 5 & 4.04 & .878 \\
\hline $\begin{array}{l}\text { The purposes for which Social Media was } \\
\text { used by Human Resource managers were } \\
\text { almost solely for the hiring decision. }\end{array}$ & UBH3 & 80 & 1 & 5 & 3.61 & .961 \\
\hline $\begin{array}{l}\text { The purposes for which SM was used by } \\
\text { Human Resource managers were almost } \\
\text { solely for interview. }\end{array}$ & UBH4 & 80 & 1 & 5 & 3.48 & 1.125 \\
\hline $\begin{array}{l}\text { The purposes for which SM was used by } \\
\text { Human Resource managers were almost } \\
\text { solely for reference checking. }\end{array}$ & UBH5 & 80 & 1 & 5 & 3.65 & .982 \\
\hline $\begin{array}{l}\text { The purposes for which SM was used by } \\
\text { solely for initial screening. }\end{array}$ & UBH6 & 80 & 2 & 5 & 3.62 & .905 \\
\hline
\end{tabular}

Usage behavior in Recruitment

\begin{tabular}{|l|l|l|l|l|l|l|l|}
\hline $\begin{array}{l}\text { Social Media was most useful for } \\
\text { collaborating directly with possible } \\
\text { candidates. }\end{array}$ & UBR1 & 80 & 2 & 5 & 3.93 & .839 \\
\hline $\begin{array}{l}\text { Social Media was most useful for sourcing } \\
\text { and identifying potential candidates. }\end{array}$ & UBR2 & 80 & 2 & 5 & 4.01 & .720 \\
\hline $\begin{array}{l}\text { Social Media was most useful for } \\
\text { screening candidates. UBR3 }\end{array}$ & 80 & 2 & 5 & 4.05 & .899 \\
\hline
\end{tabular}


Usage behavior across job types

\begin{tabular}{|l|l|l|l|l|l|l|}
\hline $\begin{array}{l}\text { Social Media is useful for recruiting full } \\
\text { time front line employees. }\end{array}$ & UBJ1 & 80 & 2 & 5 & 3.89 & .779 \\
\hline $\begin{array}{l}\text { Social Media is useful for recruiting part } \\
\text { time front line employees. }\end{array}$ & UBJ2 & 80 & 2 & 5 & 3.66 & .762 \\
\hline $\begin{array}{l}\text { Social Media is useful for recruiting } \\
\text { employees at management level. }\end{array}$ & UBJ3 & 80 & 1 & 5 & 3.76 & 1.046 \\
\hline $\begin{array}{l}\text { Social Media is useful for recruiting } \\
\text { employees at supervisory levels. }\end{array}$ & UBJ4 & 80 & 1 & 5 & 3.49 & 1.067 \\
\hline $\begin{array}{l}\text { Social Media is useful for recruiting } \\
\text { seasonal workers/ employees. }\end{array}$ & UBJ5 & 80 & 1 & 5 & 3.46 & .913 \\
\hline
\end{tabular}

Behavioral intention

\begin{tabular}{|l|l|l|l|l|l|l|}
\hline $\begin{array}{l}\text { Keeping up with the rising use of social } \\
\text { media is difficult for human resource } \\
\text { managers. }\end{array}$ & BI1 & 80 & 1 & 5 & 3.49 & 1.201 \\
\hline $\begin{array}{l}\text { Social media is a cost effective tool for } \\
\text { human resource purposes. }\end{array}$ & BI2 & 80 & 1 & 5 & 3.81 & 1.057 \\
\hline $\begin{array}{l}\text { Social media is more effective for } \\
\text { recruiting employees than more traditional } \\
\text { methods such as newspaper } \\
\text { advertisements and job websites. }\end{array}$ & BI3 & 80 & 2 & 5 & 4.34 & .655 \\
\hline $\begin{array}{l}\text { Use of social media by human resource } \\
\text { purposes has too many ethical and privacy } \\
\text { issues related to it. }\end{array}$ & BI4 & 80 & 1 & 5 & 3.91 & 1.009 \\
\hline $\begin{array}{l}\text { Social media should have a vital role in } \\
\text { the hiring process. }\end{array}$ & BI5 & 80 & 1 & 5 & 3.88 & .973 \\
\hline $\begin{array}{l}\text { Usage of social media in human resources } \\
\text { is a fad. }\end{array}$ & BI6 & 80 & 1 & 5 & 3.17 & 1.220 \\
\hline
\end{tabular}




\begin{tabular}{|c|c|c|c|c|c|c|}
\hline $\begin{array}{l}\text { I plan to use social media in the next } 12 \\
\text { months }\end{array}$ & $\mathrm{BI7}$ & 80 & 1 & 5 & 3.91 & 1.058 \\
\hline \multicolumn{7}{|l|}{ Performance expectancy } \\
\hline I find social media useful in my job & PE1 & 80 & 1 & 5 & 3.91 & .917 \\
\hline $\begin{array}{l}\text { Using social media increase my } \\
\text { productivity }\end{array}$ & PE2 & 80 & 2 & 5 & 4.09 & .845 \\
\hline \multicolumn{7}{|l|}{ Social influence } \\
\hline $\begin{array}{l}\text { People who are significant to me think I } \\
\text { should use social media }\end{array}$ & SI1 & 80 & 1 & 5 & 4.06 & .817 \\
\hline $\begin{array}{l}\text { In general, my company provisions the } \\
\text { usage of social media }\end{array}$ & SI2 & 80 & 2 & 5 & 3.93 & .708 \\
\hline \multicolumn{7}{|l|}{ Facilitating condition } \\
\hline $\begin{array}{l}\text { I have the resource necessary to use social } \\
\text { media }\end{array}$ & FC1 & 80 & 1 & 5 & 4.06 & .752 \\
\hline $\begin{array}{l}\text { I have the knowledge necessary to use } \\
\text { social media }\end{array}$ & FC2 & 80 & 1 & 5 & 3.74 & .938 \\
\hline $\begin{array}{l}\text { A precise individual (or group) is } \\
\text { available for help }\end{array}$ & FC3 & 80 & 2 & 5 & 4.15 & .677 \\
\hline \multicolumn{7}{|l|}{ Effort Expectancy } \\
\hline It is easy for me to master social media. & $\mathrm{EE}$ & 80 & 2 & 5 & 4.09 & .750 \\
\hline
\end{tabular}


Table 10. Descriptive Statistics of Variables

\begin{tabular}{|l|r|r|r|r|r|}
\hline & \multicolumn{1}{|c|}{$\mathrm{N}$} & Minimum & Maximum & \multicolumn{1}{c|}{ Mean } & \multicolumn{1}{c|}{$\begin{array}{c}\text { Std. } \\
\text { Deviation }\end{array}$} \\
\hline Behavior in Hiring & 80 & 2.67 & 4.83 & 3.7625 & .55358 \\
\hline Usage Behavior in Recruitment & 80 & 2.20 & 5.00 & 3.6525 & .64021 \\
\hline Usage Behavior across job types & 80 & 2.20 & 5.00 & 3.6525 & .64021 \\
\hline Behavioral Intention & 80 & 2.57 & 5.00 & 3.7875 & .53113 \\
\hline Performance Expectancy & 80 & 2.00 & 5.00 & 4.0000 & .71600 \\
\hline Social Influence & 80 & 2.50 & 5.00 & 3.9937 & .65359 \\
\hline Facilitating Condition & 80 & 2.33 & 5.00 & 3.9833 & .59510 \\
\hline Effort Expectancy & 80 & 2.00 & 5.00 & 4.0875 & .74958 \\
\hline
\end{tabular}

Table 11. Correlation Analysis

\begin{tabular}{|l|c|c|c|c|c|c|c|c|}
\hline \multicolumn{7}{|c|}{ Correlations Analysis } \\
\hline & UBH & UBR & UBJ & BI & PE & SI & FC & EE \\
\hline Usage Behavior in Hiring & 1.000 & .406 & .406 & .143 & .296 & .228 & .069 & .259 \\
\hline Usage Behavior in Recruitment & .406 & 1.000 & 1.000 & .303 & .341 & .252 & .229 & .396 \\
\hline Usage Behavior across job types & .406 & 1.000 & 1.000 & .303 & .341 & .252 & .229 & .396 \\
\hline Behavioral Intention & .143 & .303 & .303 & 1.000 & .257 & .405 & .376 & .116 \\
\hline Performance Expectancy & .296 & .341 & .341 & .257 & 1.000 & .414 & .382 & .296 \\
\hline Social Influence & .228 & .252 & .252 & .405 & .414 & 1.000 & .308 & .170 \\
\hline
\end{tabular}




\begin{tabular}{|l|r|r|r|r|r|r|r|r|}
\hline Facilitating Condition & .069 & .229 & .229 & .376 & .382 & .308 & 1.000 & .330 \\
\hline Effort Expectancy & .259 & .396 & .396 & .116 & .296 & .170 & .330 & 1.000 \\
\hline & \begin{tabular}{l}
$*$. Correlation is significant at the 0.05 level. \\
\hline
\end{tabular}
\end{tabular}

The highest coefficient of correlation is performance expectancy because it every HR personal want to perform best by using social Media tools collectively in all activities in HR while the least is Social Media Influence because most of the people still thinking about that in our region people still not using SM for constructive purposes but it is a mixed opinion according to people age and experience but we can't ignore this as it is also one of the component which impacts on the recruitment through social media.

\subsection{Structural Equation Modeling}

Two distinct PLS runs were led to inspect the direct and directed impacts speculated in the examination display. Collinearity is typically evaluated before the SEM investigation is led, and a notice is shown about it (Moqbel, Nevo, Kock, \& People, 2013). For our data set no collinearity issues were identified, and a further examination of the resistance (VIF) values for all builds uncovered that they were all over 0.20 and underneath 5 as required in PLS-SEM (F. Hair Jr, Sarstedt, Hopkins, \& G. Kuppelwieser, 2014).

In Figure 1, an examination of the structural model indicated that performance expectancy $(\beta$ $=.0 .17 ; \mathrm{p}=.06)$, effort expectancy $(\beta=.28 ; \mathrm{p}<.01)$, Facilitating Conditions $(\beta=.64 ; \mathrm{p}<.01)$ and social influence $(\beta=.28 ; \mathrm{p}<.05)$ were all noteworthy factors of the intention to use social media sites in hiring. These three paradigms clarified 37 percent of the variance in behavioral intention (adjusted $\mathrm{R}^{2}=.84$ ). These outcomes deliver support for the hypotheses. 


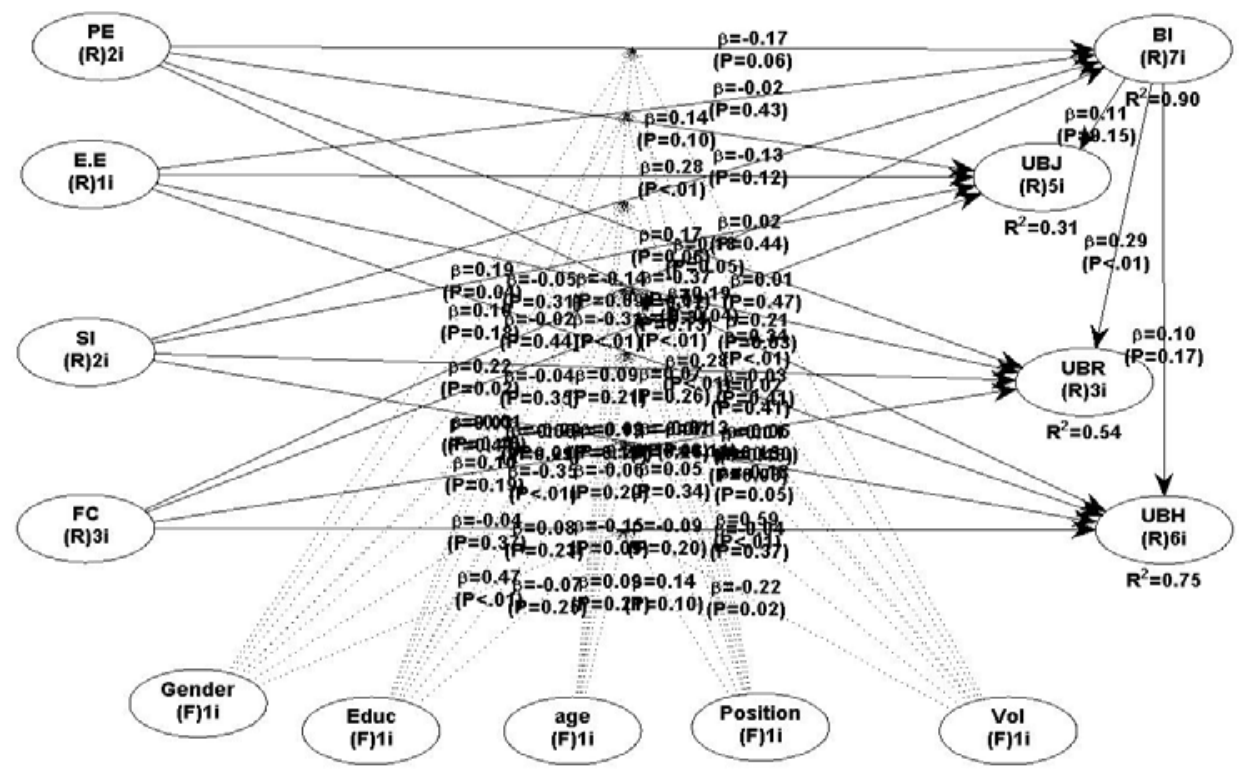

Figure 2. Path coefficients and $\mathrm{R}^{2}$ values for structural model 2

Note: Only noteworthy paths are displayed. Significance at the ${ }^{*} .05,{ }^{* *} .01$, and ${ }^{* * *} .001$ levels.

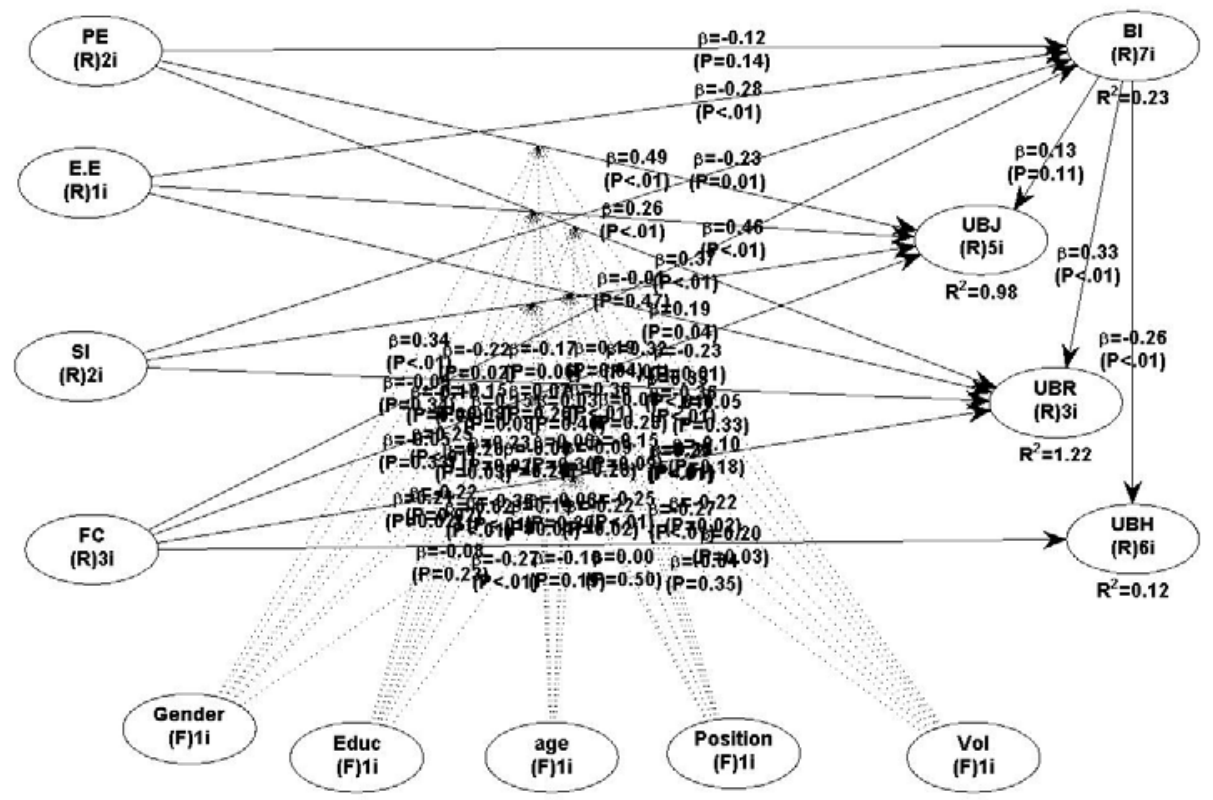

Figure 3. Path coefficients and $\mathrm{R}^{2}$ values for structural model 


\subsubsection{Measurement of Outer Model}

The goal of measure of appropriate in the Measurement Model is to study about the reliability and rationality of the tool and to check its reliability and validity we perform test of convergent validity and discriminant validity in software naming Smart PLS.

\subsubsection{Composite Reliability}

Reliability of the measurement instruments was evaluated using composite reliability. All the standards were overhead the normally used verge value i.e. 0.70. This is the accepted reliability value range. Estimation of reliability can be done by degree of constancy that lies amongst various variables (F. Hair Jr et al., 2014). Below is the table of composite reliability.

Table 12. Composite Reliability

\begin{tabular}{|l|r|}
\hline Variables & Composite Reliability \\
\hline Behavioral Intention & 0.783 \\
\hline Effort Expectancy & 1 \\
\hline Facilitating Condition & 0.794 \\
\hline Performance Expectancy & 0.795 \\
\hline Social Influence & 0.844 \\
\hline Usage Behavior in Hiring & 0.717 \\
\hline Usage Behavior across job types & 0.792 \\
\hline Usage Behavior in Recruitment & 0.831 \\
\hline
\end{tabular}

\subsubsection{Factor loadings significant}

Below is the mentioned table of (CFA) confirmatory factor analysis with the loadings. Construct with the loading of .5 are consider as strong loading variables whereas the constructs with the loading of below .5 are considered as less are better to be removed from the table.

Table 13. Factor Loading Significance

\begin{tabular}{|l|l|l|l|l|}
\hline & Constructs & Item & T-value & P-Value \\
\hline
\end{tabular}




\begin{tabular}{|c|c|c|c|c|}
\hline \multirow{7}{*}{$\begin{array}{l}\text { Frequency of Use of Social Media } \\
\text { across Stages of Hiring: }\end{array}$} & & loading & & \\
\hline & $\begin{array}{l}\text { Usage behavior } \\
\text { in hiring1 }\end{array}$ & 1.0762 & 4.777 & .000 \\
\hline & $\begin{array}{l}\text { Usage behavior } \\
\text { in hiring1 }\end{array}$ & 0.6494 & 7.570 & .000 \\
\hline & $\begin{array}{l}\text { Usage behavior } \\
\text { in hiring1 }\end{array}$ & 0.7261 & 5.700 & .000 \\
\hline & $\begin{array}{l}\text { Usage behavior } \\
\text { in hiring1 }\end{array}$ & 1.0562 & 3.777 & .000 \\
\hline & $\begin{array}{l}\text { Usage behavior } \\
\text { in hiring1 }\end{array}$ & 0.5146 & 5.980 & .000 \\
\hline & $\begin{array}{l}\text { Usage behavior } \\
\text { in hiring1 }\end{array}$ & 0.5419 & 6.175 & .000 \\
\hline \multirow{3}{*}{$\begin{array}{l}\text { Usefulness of Social Media for HR } \\
\text { Purposes: }\end{array}$} & $\begin{array}{l}\text { Usage behavior } \\
\text { in Recruitment1 }\end{array}$ & 0.5440 & 9.866 & .000 \\
\hline & $\begin{array}{l}\text { Usage behavior } \\
\text { in Recruitment2 }\end{array}$ & 0.5274 & 12.573 & .000 \\
\hline & $\begin{array}{l}\text { Usage behavior } \\
\text { in Recruitment3 }\end{array}$ & 0.5465 & 10.451 & .000 \\
\hline \multirow{4}{*}{$\begin{array}{l}\text { Related with } \\
\text { Employees }\end{array}$} & $\begin{array}{l}\text { Usage behavior } \\
\text { across job types1 }\end{array}$ & 0.5809 & 10.107 & .000 \\
\hline & $\begin{array}{l}\text { Usage behavior } \\
\text { across job types } 2\end{array}$ & 0.63343 & 6.775 & .000 \\
\hline & $\begin{array}{l}\text { Usage behavior } \\
\text { across job types3 }\end{array}$ & 0.8491 & 6.518 & .000 \\
\hline & $\begin{array}{l}\text { Usage behavior } \\
\text { across job types4 }\end{array}$ & 0.5577 & 4.085 & .000 \\
\hline
\end{tabular}




\begin{tabular}{|c|c|c|c|c|}
\hline & $\begin{array}{l}\text { Usage behavior } \\
\text { across job types5 }\end{array}$ & 0.4840 & 4.530 & .000 \\
\hline \multirow{7}{*}{$\begin{array}{l}\text { Behavioral intention toward Social } \\
\text { Media Use for Human Resources }\end{array}$} & $\begin{array}{l}\text { Behavioral } \\
\text { intention1 }\end{array}$ & 1.1497 & 3.630 & .001 \\
\hline & $\begin{array}{l}\text { Behavioral } \\
\text { intention2 }\end{array}$ & 0.8607 & 6.878 & .000 \\
\hline & $\begin{array}{l}\text { Behavioral } \\
\text { intention3 }\end{array}$ & 0.8432 & 8.2666 & .000 \\
\hline & $\begin{array}{l}\text { Behavioral } \\
\text { intention4 }\end{array}$ & 0.6545 & 8.0291 & .000 \\
\hline & $\begin{array}{l}\text { Behavioral } \\
\text { intention5 }\end{array}$ & 0.5408 & 8.046 & .000 \\
\hline & $\begin{array}{l}\text { Behavioral } \\
\text { intention6 }\end{array}$ & 0.7107 & 1.283 & .001 \\
\hline & $\begin{array}{l}\text { Behavioral } \\
\text { intention7 }\end{array}$ & 0.5015 & 7.716 & .000 \\
\hline \multirow{2}{*}{ Related with performance expectancy } & $\begin{array}{l}\text { performance } \\
\text { expectancy1 }\end{array}$ & 0.5084 & 8.903 & .000 \\
\hline & $\begin{array}{l}\text { performance } \\
\text { expectancy2 }\end{array}$ & 0.5822 & 11.513 & .000 \\
\hline \multirow{3}{*}{ Related with social influence } & $\begin{array}{l}\text { Social } \\
\text { influence1 }\end{array}$ & 0.6828 & 11.637 & .000 \\
\hline & $\begin{array}{l}\text { Social } \\
\text { influence2 }\end{array}$ & 0.7913 & 9.693 & .000 \\
\hline & $\begin{array}{l}\text { Facilitating } \\
\text { condition1 }\end{array}$ & 0.5704 & 10.636 & .000 \\
\hline
\end{tabular}




\begin{tabular}{|l|l|l|l|l|}
\hline Related to facilitating condition & $\begin{array}{l}\text { Facilitating } \\
\text { condition2 }\end{array}$ & 0.6853 & 7.033 & .000 \\
\cline { 2 - 6 } & $\begin{array}{l}\text { Facilitating } \\
\text { condition3 }\end{array}$ & 0.5203 & 10.195 & .000 \\
\hline Related with effort expectancy & $\begin{array}{l}\text { Effort } \\
\text { expectancy }\end{array}$ & 0.7449 & 12.976 & .000 \\
\hline
\end{tabular}

\subsubsection{Convergent Validity}

Convergent validity is the level of arrangement in at least 2 measures of a similar paradigm (Carmines \& Zeller, 1979). Convergent validity was assessed by inspection of variance mined for every factor (Fornell \& Larcker, 1981). Conferring to Fornell and Larcker (1981), if the, variance extracted value is greater than 0.5 then convergent validity is established. Following table displays the result.

Table 14. Convergent Validity

\begin{tabular}{|l|r|r|r|r|}
\hline & Cronbach's Alpha & \multicolumn{1}{|c|}{ rho_A } & Composite Reliability & $\begin{array}{r}\text { Average Variance } \\
\text { Extracted (AVE) }\end{array}$ \\
\hline BI & 0.535 & 0.677 & 0.631 & 0.265 \\
\hline EE1 & 1 & 1 & 1 & 1 \\
\hline FC & 0.616 & 0.634 & 0.794 & 0.563 \\
\hline PE & 0.485 & 0.49 & 0.795 & 0.66 \\
\hline SI & 0.638 & 0.673 & 0.844 & 0.731 \\
\hline UBH & 0.587 & 0.572 & 0.717 & 0.333 \\
\hline UBJ & 0.726 & 0.772 & 0.792 & 0.446 \\
\hline UBR & 0.704 & 0.743 & 0.831 & 0.624 \\
\hline
\end{tabular}

4.6.5 Reliability and Validity

The table above also indicates about the reliability and validity of the interrelated variables.

The notion of reliability assists to demonstrate about the consistency among the multiple 
variables and has been measured with the help of the PLS software. The study has been doing the reliability test by linking it with the Cronbach's alpha with objective to measure the reliability of the scale. The present study has also followed the Cronbach approach to see the reliability of the scale which should always be higher than the value of 0.7 to ensure higher internal consistency. Thus, it has been noted that the Cronbach value for Effort Expectancy is 1 which depicts the higher consistency. On the other hand, UBJ and UBR also shows strong internal consistency by having the Cronbach value of 0.726 and 0.704 . This implies that the variables have been closely linked with each other.

\subsubsection{Discriminant Validity}

Discriminate validity can be defined as any single construct when differs from other constructs in the model (Carmines \& Zeller, 1979). Discriminate validity results are satisfactory when the constructs are having an AVE loading more than 0.5 which means that minimum 50\% of variance was took by the construct (Chin, 1998). Discriminate validity is established if the elements which are in diagonal are significantly higher than those values in off-diagonal in the parallel rows and columns.

Table 15. Discriminant Validity

\begin{tabular}{|l|r|r|r|r|r|l|l|l|}
\hline & \multicolumn{1}{l|l}{ BI } & \multicolumn{1}{l|l}{ EE1 } & \multicolumn{1}{l|l}{ FC } & \multicolumn{1}{l|}{ SE } & UBH & UBJ & UBR \\
\hline BI & 0.514 & & & & & & & \\
\hline EE1 & 0.416 & 1 & & & & & & \\
\hline FC & 0.595 & 0.473 & 0.75 & & & & & \\
\hline PE & 0.615 & 0.29 & 0.471 & 0.812 & & & & \\
\hline SI & 0.719 & 0.197 & 0.465 & 0.583 & 0.855 & & & \\
\hline UBH & 0.424 & 0.244 & 0.232 & 0.51 & 0.433 & 0.577 & & \\
\hline UBJ & 0.57 & 0.496 & 0.489 & 0.424 & 0.429 & 0.42 & 0.668 & \\
\hline UBR & 0.542 & 0.4 & 0.55 & 0.548 & 0.526 & 0.466 & 0.608 & 0.79 \\
\hline
\end{tabular}

\subsubsection{Model Fit Measures}

The wellness of the model in SEM-PLS is characterized by different estimates, for example, institutionalized root-mean-square remaining (SRMR), and the accurate model fits like d_ULS and d_G, Normed Fit Index (NFI), and $\chi 2$ (Chi-square). The model fit measures 


\section{Macrothink}

Business Management and Strategy

ISSN 2157-6068

2019, Vol. 10, No. 1

comprising the deliberate estimation of both soaked model just as the evaluated model is accounted for in above Table. The immersed model surveys the connection between's everything develops. The assessed model, then again, considers show structure and depends on all out impact plot. Presently, we will portray each model fit measure in subtleties to comprehend its suggestions.

\subsubsection{Standardized Root-Mean-Square Residual}

The SRMR measure depends on changing both the covariance networks, test and anticipated covariance grid into the correlation matrix and afterward figuring the contrast between the model's suggested correlation matrix and the observed correlation. The SRMR esteem ought to be under 0.10 for thinking about any model to have a solid match (Hu \& Bentler, 1998). The suggested model yields the SRMR value as 0.06, which is relatively lesser than 0.10 . Hence, the proposed model is a good fit.

Table 16. Standardized Root-Mean-Square Residual

\begin{tabular}{|l|r|r|}
\hline & Saturated Model & \multicolumn{2}{|l|}{ Estimated Model } \\
\hline SRMR & 0.165 & 0.169 \\
\hline d_ULS & 11.833 & 12.399 \\
\hline d_G & 4.096 & 4.211 \\
\hline Chi-Square & $1,340.53$ & $1,356.33$ \\
\hline NFI & 0.236 & 0.227 \\
\hline
\end{tabular}

4.6.9 Hypothesis Testing

Table 17. Hypothesis Decisions

\begin{tabular}{|c|c|c|c|c|}
\hline Hypothesis & $\begin{array}{l}\text { Standard } \\
\text { Deviation } \\
\text { (STDEV) }\end{array}$ & T-values & $\mathbf{P}$-values & Decision \\
\hline BI $->$ FC & 0.120 & 4.072 & 0.000 & Supported \\
\hline BI $->$ PE & 0.107 & 3.852 & 0.000 & Supported \\
\hline & & & & Supported \\
\hline
\end{tabular}




\section{Macrothink}

Business Management and Strategy

ISSN 2157-6068

2019, Vol. 10, No. 1

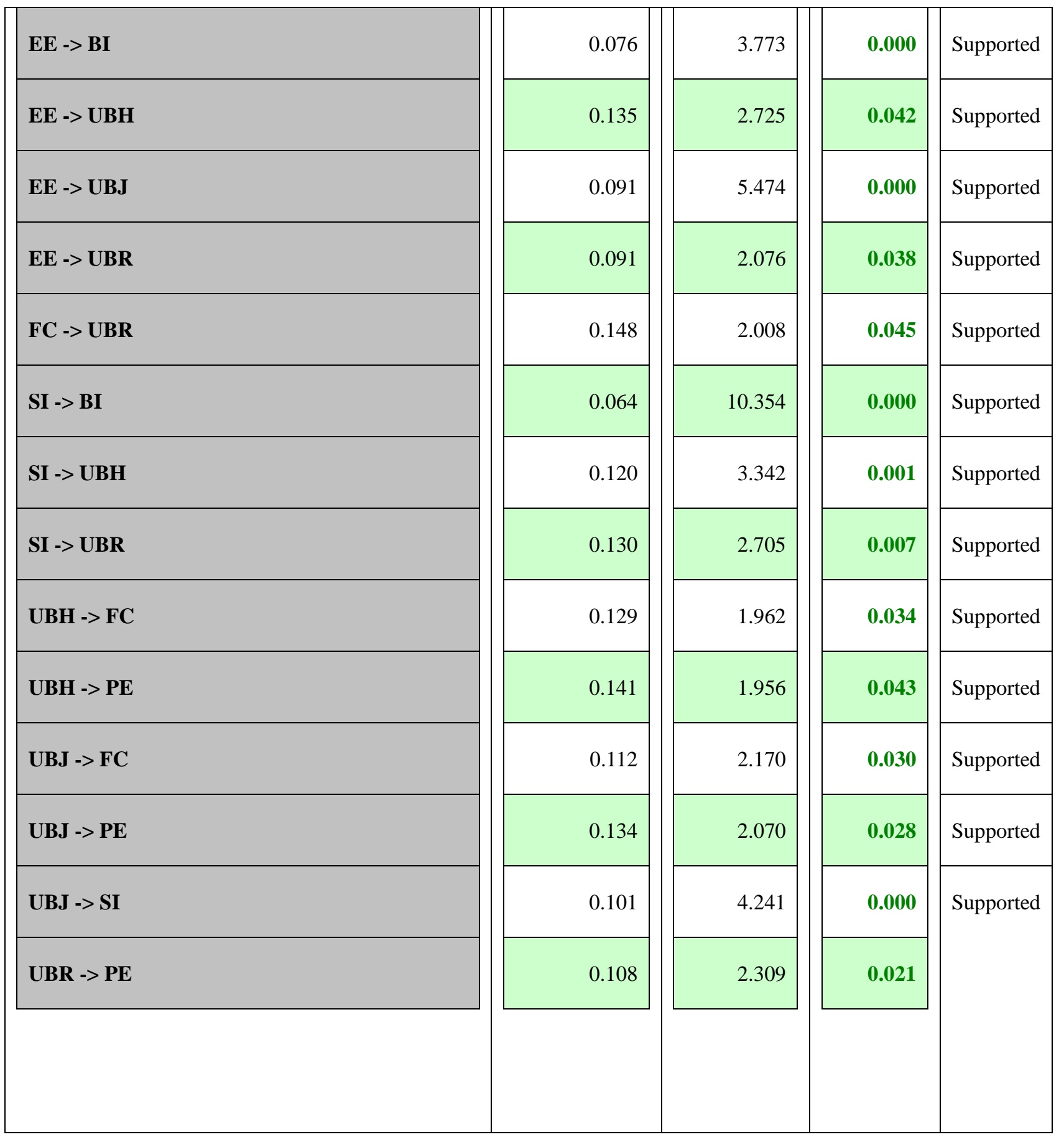

Above is the table which displays the results of hypothesis, the variables having relationship is positive as the t-value $>1.96$ (for 2-tailed) which is equivalent to $\mathrm{p}<0.05$ positive impact on recruitment in service industry. The $T$ value shows there is a significant difference among the variables and the $\mathrm{P}$ values depicts the decision no relation has been rejected and the alternative hypothesis have been supported on the basis of $\mathrm{p}$ values.

\section{Result \& Discussion}

In this study, we analyses social media usage by different key personals in different people working in services industries in Pakistan to social-media networking adoption in employee's 
recruitment process in Pakistan. In accordance with the speculations of the model, the after effects of the present investigation demonstrated that the goal to utilize social media based in hiring was dependent on the view of their potential employment related additions, their apparent convenience, and their apparent significance by socially compelling people. The finding that execution anticipation was the most grounded indicator. For the genuine utilization of online networking, both execution anticipation and encouraging conditions were huge indicators.

The moderated model exposed three main unforeseen discoveries. Initial, contrary to previous discoveries in Venkatesh et al. (2003) think about which placed sexual orientation contrasts dependent on discernment identified with gender based jobs, we found that male, as opposed to female, selection representatives were the ones who revealed exertion anticipation and social impact as solid determinants of their goal to utilize social networking sites Extra factors, for example, the gender orientation creation of gatherings, the correspondence style of interweaves, and the gender predisposition of the undertaking (Carli, 2001) may clarify these startling gender collaborations. For instance, in the course of recent years, men in the Pakistan have been more probable than ladies to utilize social networking sites. Thus, all things considered, men may have turned out to be more comfortable than females with these advancements, and therefore experience less trouble in receiving them for expert purposes. While different analysts found that gender contrasts were chronologically erroneous and no longer important in innovation use and selection in present day and innovation educated civilizations (Workman \& Reader, 2014), our examination demonstrated that sexual orientation contrasts continued in Pakistan regarding execution hope which was more grounded for men, and rather moved as far as exertion anticipation and social impact for females who never again discover online social networking sites to utilize or feel social strain to embrace them. At the end of the day, for male recruiting specialists, the goal to receive social media sites was emphatically dependent on employment related gains of course, yet additionally on convenience and on social impact in opposition to desires.

The second unforeseen finding in this examination was the specific importance of both exertions hope and social impact for more young hiring specialist. As far as exertion anticipation, it is conceivable that more young candidates, who for the most part utilize on social networking for diversion and interfacing with companions, face new difficulties in the working environment with the expert utilization of these innovations. In an investigation on the thought processes of Internet use in Pakistan, social media and amusement related use was essentially anticipated by more youthful age and lower training levels, while work and data related use was lower for both younger and more established clients, yet more grounded for recruiters matured somewhere in the range of 26 and 30 and those with larger amounts of instruction. As to impact, Venkatesh et al. (2003) set that more older employees would have more prominent trouble in managing new innovation, and would feel more prominent alliance needs subsequently setting expanded remarkable quality on social impacts. Our discoveries, be that as it may, showed the affect-ability of more youthful spotters to social impact. This could be on the grounds that youthful clients are especially touchy to peer strain 
to receive and utilize social media networking sites when all is said in done (Trottier, 2012), what's more, this impact may stretch out to the work environment. This elective clarification is in accordance with meta-expository discoveries on the contrary connection among age and social work thought processes, with more youthful specialists demonstrating more grounded intentions related with associations with other individuals including colleagues (Kooij, De Lange, Jansen, Kanfer, \& Dikkers, 2011). Paralleled to older workers, newer ones also have tougher growth causes in terms of new knowledge, training and progression (Kooij et al., 2011), and might so be more sensitive to supposed social influence at the office to adopt innovation and development in their professions.

The third sudden finding in this examination was the essentialness of social impact's effect on Social Media for enlistment purposes for exceptionally taught enrollment specialists and in willful settings. To start with, having a propelled degree is a huge indicator of taking part in expert exercises and expanding inside perceptibility at the working environment (Forret, Dougherty, \& Management, 2001). On social media, highly educated users are more inspired by communal attentiveness, social engagement and status (Syn \& Oh, 2015). It is along these lines conceivable that very instructed people are progressively presented to social impact in expert settings, on and off online life, and are increasingly delicate to this weight. Additional, Venkatesh et al. (2003) placed and found that social impact was more grounded in obligatory settings because of consistence. In any case, we found that hiring specialists who had the opportunity to utilize social media networking were the most delicate to social impact. An examination on data innovation use in wellbeing focuses in Thailand found that intentionality directly affected Human Resource exercises, as the impression of opportunity of decision positively affected the aim to utilize the innovation (Kijsanayotin, Pannarunothai, \& Speedie, 2009). Besides, in Pakistan where conservatism and amicability esteems are embraced, social help as colleague instrumental help is esteemed by workers (Glazer, 2006). It is consequently conceivable that social influence is robust in all sceneries in this area.

The significance of social impact specifically for some classifications of hiring specialists in our research could be because of its situational setting. Social standards apply the best impact when conditions are questionable, or when people are especially worried about building up or keeping up an association with the source (Cialdini \& Trost, 1998). In addition, independence has a negative association with helplessness to regulating impact (Mourali, Laroche, \& Pons, 2005). An inspection of the rationalized scores of Hofstede and Bond (1984) social measurements demonstrated that, by and large, the sampled Pakistan have high scores in power separation and vulnerability evasion, and low scores on independence. It is along these lines conceivable that the respondents are exceptionally defenseless to social influence because of their countrywide cultures.

\section{Conclusion}

In this section this researcher means to have a talk that will include a general examination or study of the overview results exhibited above with regards to what was recently seen in the literature review part thusly, this analyst intends to make the learning important to get to an 
end on the general research and along these lines answer the exploration questions recently proposed.

The overview that was displayed and broke down above was worked to assemble the most pertinent data with respect to the present practices in the utilization of internet based life for enrollment purposes, the future patterns not out of the ordinary, the difficulties of utilizing such practice. There was a beneficial outcome of execution anticipation, exertion hope and social effect on selection representative's expectation to utilize these innovations enlistment. Moreover, encouraging conditions and social aim impactsly affect the scout's use conduct. There is a drive impact of various mediators like sexual orientation, age, training, and administrative position, for example, the impact is more grounded for male, more youthful and high situated scouts while the majority of the accomplished selection representatives still underline on customary methodologies however adjacent to all these online social media sites appear to have a critical effect during the time spent enrollment of staff in any organization.

Having these viewpoints dissected and talked about it appears to be sensible to state that the examination has been effective in addressing the proposed inquiries with respect to the practices as of now set up, future desires and inclines, and the hazards associated with the utilization of web based social media networking sites as apparatus in the enlistment procedure, all from a businesses' point of view.

\section{Acknowledgement}

Above all I want to thank to Almighty "ALLAH” who is most tolerant and kind and who makes me ready to set up this research study.

I generously appreciate my research supervisor, Sir Danish Ahmed Siddiqui, whose support and assistance from the beginning step to the last level permitted me to build up an understanding of the methodology of conducting research and authorised me to build up a comprehension of the approach of leading research exploration.

Also, I would like to express my gratitude to my parents Abdul Aqeel \& Samina Aqeel and my fellow student Ahsan Khan, for their support and patience, for keeping me motivated.

My research work has benefited from the insightful direction of numerous colleagues, teachers, family members and more numerous than I can fully acknowledge here. I would like to acknowledge those who contributed in the occasions that I conducted discussions to get formal feedback on my research topic that is "The Effect of Social Media Following on Recruitment in Service Industries of Pakistan”

Lastly, I offer my respects and endowments to all those who trusted and supported me in any regard during the fulfilment of the research study.

\section{References}

A. Carrillat, F., d’Astous, A., \& Morissette Grégoire, E. J. I. R. (2014). Leveraging social media to enhance recruitment effectiveness: a Facebook experiment, 24(4), 474-495. 
Abel, F., Gao, Q., Houben, G.-J., \& Tao, K. (2011). Analyzing temporal dynamics in twitter profiles for personalized recommendations in the social web. Paper presented at the Proceedings of the 3rd International Web Science Conference.

Andzulis, J. M., Panagopoulos, N. G., Rapp, A. J. J. o. P. S., \& Management, S. (2012). A review of social media and implications for the sales process, 32(3), 305-316.

Berkowitz, M. J. J. o. P. I. M. (1987). Product shape as a design innovation strategy, 4(4), 274-283.

Brotherton, P. J. T. D. (2012). Social media and referrals are best sources for talent, 66(1), 24.

Caers, R., \& Castelyns, V. J. S. S. C. R. (2011). LinkedIn and Facebook in Belgium: The influences and biases of social network sites in recruitment and selection procedures, 29(4), 437-448.

Cain, J., Scott, D. R., \& Smith, K. J. A. J. o. H.-S. P. (2010). Use of social media by residency program directors for resident selection, 67(19), 1635-1639.

Carli, L. L. J. J. o. S. I. (2001). Gender and social influence, 57(4), 725-741.

Carmines, E. G., \& Zeller, R. A. (1979). Reliability and validity assessment (Vol. 17): Sage publications.

Chin, W. W. J. M. m. f. b. r. (1998). The partial least squares approach to structural equation modeling, 295(2), 295-336.

Cialdini, R. B., \& Trost, M. R. (1998). Social influence: Social norms, conformity and compliance.

Crisp, B. R., Anderson, M., Orme, J., \& Lister, P. G. (2003). Learning and teaching in social work education: Assessment: Social Care Institute for Health.

Deloitte Consulting, L., \& by Deloitte, B. (2014). Global human capital trends 2014: engaging the 21st century workforce. In: Deloitte University Press.

Doherty, R. J. S. H. r. (2010). Getting social with recruitment, 9(6), 11-15.

Edition, T. B. J. D., CA: Taleo Corporation. (2010). Social network recruiting: managing compliance issues.

El Ouirdi, A., El Ouirdi, M., Segers, J., Henderickx, E. J. B., \& Technology, I. (2015). Employees' use of social media technologies: a methodological and thematic review, 34(5), 454-464.

F. Hair Jr, J., Sarstedt, M., Hopkins, L., \& G. Kuppelwieser, V. J. E. B. R. (2014). Partial least squares structural equation modeling (PLS-SEM) An emerging tool in business research, 26(2), 106-121.

Festing, M., Schäfer, L., \& Scullion, H. J. T. I. J. o. H. R. M. (2013). Talent management in 
medium-sized German companies: an explorative study and agenda for future research, 24(9), 1872-1893.

Fornell, C., \& Larcker, D. F. (1981). Structural equation models with unobservable variables and measurement error: Algebra and statistics. In: SAGE Publications Sage CA: Los Angeles, CA.

Forret, M. L., Dougherty, T. W. J. G., \& Management, O. (2001). Correlates of networking behavior for managerial and professional employees. 26(3), 283-311.

Garcia-Retamero, R., Galesic, M. J. S. s., \& medicine. (2010). Who proficts from visual aids: Overcoming challenges in people's understanding of risks, 70(7), 1019-1025.

Gibbs, C., MacDonald, F., \& MacKay, K. J. I. J. o. C. H. M. (2015). Social media usage in hotel human resources: recruitment, hiring and communication, 27(2), 170-184.

Giles, M. (2010). A world of connections: A special report on social networking: Economist Newspaper.

Girard, A., \& Fallery, B. (2011). Chapter 8 e-Recruitment: From Transaction-Based Practices to Relationship-Based Approaches. In Electronic HRM in theory and practice (pp. 143-158): Emerald Group Publishing Limited.

Glazer, S. J. I. J. o. I. R. (2006). Social support across cultures, 30(5), 605-622.

Hanson, C., West, J., Neiger, B., Thackery, R., Barnes, M., \& McIntyre, E. J. A. J. o. H. E. (2011). Social Media and Health Education, 42(4), 133.

Henderson, A., \& Bowley, R. J. J. o. C. M. (2010). Authentic dialogue? The role of "friendship" in a social media recruitment campaign, 14(3), 237-257.

Hofstede, G., \& Bond, M. H. J. J. o. c.-c. p. (1984). Hofstede's culture dimensions: An independent validation using Rokeach's value survey, 15(4), 417-433.

Hu, L.-t., \& Bentler, P. M. J. P. m. (1998). Fit indices in covariance structure modeling: Sensitivity to underparameterized model misspecification, 3(4), 424.

Hunt, K. G. J. J. o. p. m. (2010). Finders keepers: Social media strategies help find top talent, 75(6), 36-41.

Khang, H., Ki, E.-J., Ye, L. J. J., \& Quarterly, M. C. (2012). Social media research in advertising, communication, marketing, and public relations, 89(2), 279-298.

Kijsanayotin, B., Pannarunothai, S., \& Speedie, S. M. J. I. j. o. m. i. (2009). Factors influencing health information technology adoption in Thailand's community health centers: Applying the UTAUT model, 78(6), 404-416.

Kooij, D. T., De Lange, A. H., Jansen, P. G., Kanfer, R., \& Dikkers, J. S. J. J. o. O. B. (2011). Age and work-related motives: Results of a meta-analysis, 32(2), 197-225. 
Madera, J. M. J. I. J. o. H. M. (2012). Using social networking websites as a selection tool: The role of selection process fairness and job pursuit intentions, 31(4), 1276-1282.

Melanthiou, Y., Pavlou, F., \& Constantinou, E. J. J. o. T. M. (2015). The use of social network sites as an e-recruitment tool, 20(1), 31-49.

Michaels, E., Handfield-Jones, H., \& Axelrod, B. (2001). The war for talent: Harvard Business Press.

Moqbel, M., Nevo, S., Kock, N. J. I. T., \& People. (2013). Organizational members' use of social networking sites and job performance: An exploratory study, 26(3), 240-264.

Mourali, M., Laroche, M., \& Pons, F. J. J. o. S. M. (2005). Individualistic orientation and consumer susceptibility to interpersonal influence, 19(3), 164-173.

Ngai, E. W., Tao, S. S., \& Moon, K. K. J. I. J. o. I. M. (2015). Social media research: Theories, constructs, and conceptual frameworks, 35(1), 33-44.

Ollington, N., Gibb, J., \& Harcourt, M. J. P. R. (2013). Online social networks: an emergent recruiter tool for attracting and screening, 42(3), 248-265.

Pelit, E., Öztürk, Y., \& Arslantürk, Y. J. I. J. o. C. H. M. (2011). The effects of employee empowerment on employee job satisfaction. A study on hotels in Turkey, 23(6), 784-802.

Pike, J. C., Bateman, P. J., \& Butler, B. J. J. o. c.-m. c. (2013). Dialectic tensions of information quality. Social networking sites and hiring, 19(1), 56-77.

Pin, J. R., Laorden, M., \& Saenz-Diez, I. (2001). Internet recruiting power: Opportunities and effectiveness.

Ployhart, R. E. J. J. o. m. (2006). Staffing in the 21st century: New challenges and strategic opportunities, 32(6), 868-897.

Recruitment, N. W. J. N. W. R., Report. (2011). The impact of social media on recruitment.

Roth, P. L., Bobko, P., Van Iddekinge, C. H., \& Thatcher, J. B. J. J. o. M. (2016). Social media in employee-selection-related decisions: A research agenda for uncharted territory, 42(1), 269-298.

Silverman, D. (2016). Qualitative research: Sage.

Slovensky, R., \& Ross, W. H. J. i. (2012). Should human resource managers use social media to screen job applicants? Managerial and legal issues in the USA, 14(1), 55-69.

Smith, W. P., \& Kidder, D. L. J. B. H. (2010). You've been tagged!(Then again, maybe not): Employers and Facebook, 53(5), 491-499.

Syn, S. Y., \& Oh, S. J. J. o. I. S. (2015). Why do social network site users share information on Facebook and Twitter? 41(5), 553-569. 


\section{IIMacrothink}

Taiwo, A. A., Downe, A. G. J. J. o. T., \& Technology, A. I. (2013). The theory of user acceptance and use of technology (UTAUT): A meta-analytic review of empirical findings, $49(1)$.

Trottier, D. J. C. J. o. C. (2012). Interpersonal surveillance on social media, 37(2).

Van Osch, W., \& Coursaris, C. K. (2015). A meta-analysis of theories and topics in social media research. Paper presented at the 2015 48th Hawaii International Conference on System Sciences.

Veil, S. R., Buehner, T., Palenchar, M. J. J. J. o. c., \& management, c. (2011). A work-in-process literature review. Incorporating social media in risk and crisis communication, 19(2), 110-122.

Venkatesh, V., Morris, M., Davis, F., \& Davis, G. J. M. I. S. Q. (2003). Unified theory of acceptance and use of technology (UTAUT), 27, 425-478.

Williams, M., Rana, N., Dwivedi, Y., \& Lal, B. (2011). Is UTAUT really used or just cited for the sake of it? A systematic review of citations of UTAUT's originating article.

Wolf, M. V., Sims, J., \& Yang, H. (2014). Social media utilization in human resource management. Paper presented at the 8th Multi Conference on Computer Science and Information Systems.

Workman, L., \& Reader, W. (2014). Evolutionary psychology: Cambridge University Press.

Zide, J., Elman, B., \& Shahani-Denning, C. J. E. R. (2014). LinkedIn and recruitment. How profiles differ across occupations, 36(5), 583-604.

\section{Copyrights}

Copyright for this article is retained by the author(s), with first publication rights granted to the journal.

This is an open-access article distributed under the terms and conditions of the Creative Commons Attribution license (http://creativecommons.org/licenses/by/4.0/) 